\title{
Paladonplatte を用いた外傷性喉頭狭窄の治験例
}

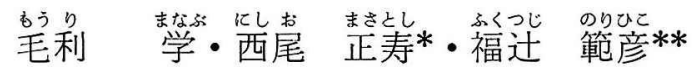

\section{I 緒言}

交通事故の增加に伴い，外鹪性喉頭狭窄症に接する機会が多くなっている．本症は患者と医師の 両者に，忍耐と努力が要求される難治の疾患の 1 つである.

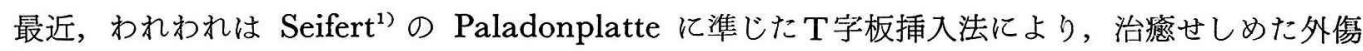
性唤頭狭窄症例を経験したので報告する。

\section{II 症 例}

症 例: 24才, 男子

主 訴: 套管抜去困難, 発声障害

既往歴，家族歴：特記すべきものなし

現病歷：昭和46年 4 月11日午後, 乗用車運転 中（いねむり運転）約 $1 \mathrm{~m}$ 下の湮飞落ちる。意 識消失, 鼻出血, 呼吸困難を来し外科病院で緊 急気管切開を受けている. 受賃 3 日後, 意識回 復しその後再三，カニューレ抜去が試みられた が，呼吸困難のため套管抜去できず，同年 5 月 20 日当科に紹介され入院す.

全身所見：脈搏 $72 / \mathrm{min} .$, 緊張良好, 血庄 $120 / 70 \mathrm{mmHg}$. 赤血球数 $398 \times 10^{4}$, 白血球 7800 血色素量 $84 \%$, 血球容積 $40 \%$ ，血小板 $15 \times 10^{4}$, 尿糖 $(-)$, 尿蛋白 $(-)$, ウロビリノーゲン (土) 胸部し線, 心電図異常所見なし.

局所久見：10号カニューレが挿管されてい る. 甲状軟骨部に軽度の圧痛を認めるが，前頸 部皮虞には発赤, 腫張, 皮下出血, 気腫などの 異常所見を認めない. 気管切開孔の周囲には肉 莱が認められ，気切孔行後宜鏡を㨉入し気管内 を観察すると, 気切孔上縁の気管前壁汇茥を持 つ肉莱が呼吸と共汇気管内で pendelnしてい る(写真 1). 喉頭鏡検祖では両側の仮声帯わよ

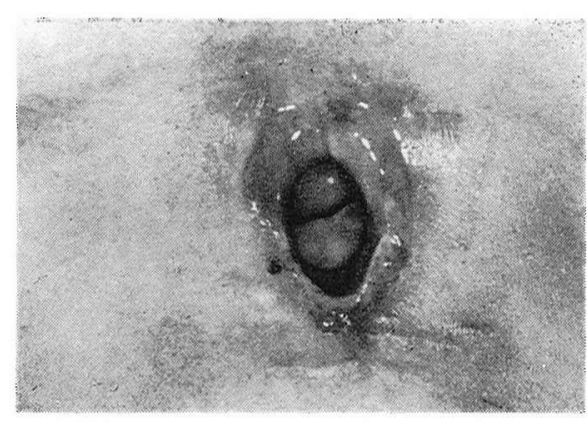

写真 1 気切周囲，気管内の肉芽を示す

び披裂部は浮腫状に腫張し，声带は明視できず 声門は完全汇閉鎖している(図 1)。更に左披裂 部の運動障害を認める. 頸部し線写真では舌骨 甲状軟骨の骨折, 位置異常は認められない。

治療と経過：5月25日, 気管切開口周国の肉 芽と気切孔上緑に茎を持ち気管内に認められる 肉芽を，電気メスで切除した。気切孔より挿管 麻酔下に啒頭直達鏡検査を行ない，浮腫状に腫 張している仮声帯をゾンデで触䛦すると，声門

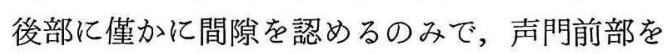
完全に閉塞し声帯は明視できない，両声帯間に 高度の瘜着があると推定され，喉頭截開術の必 要性が考元られた。

6 月 1 日, 全身麻酥下に喉頭截開術を施行し

Therapeutic Experience with Traumatic Stenosis of the Larynx Using Paladonplatte

Manabu Mōri, Masatoshi Nishio and Norihiko Fukutsuji

* 大阪四科大学耳舞咽喉科教空

** 神戸大学医学部耳界咽喉科教室 


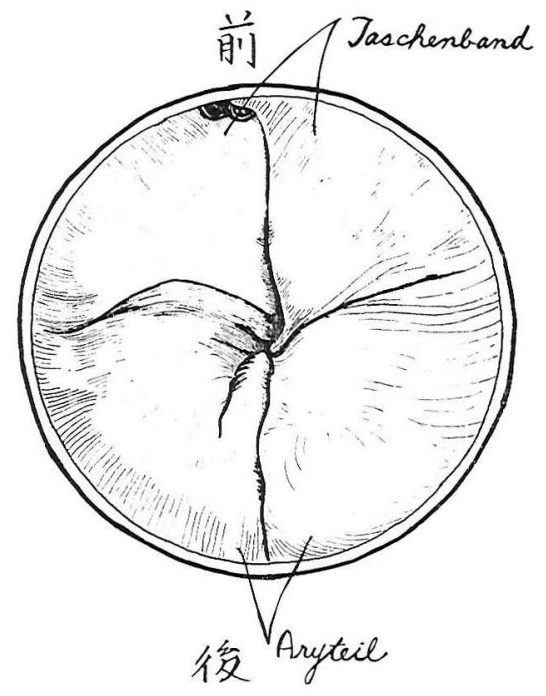

図 1 喉頭鏡検査所見

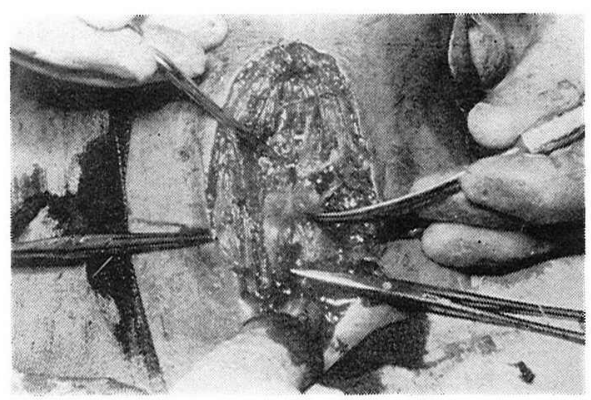

写真 2 下甲状結節，輪状甲状靱帯の陷山を示す

た．前頸部において気切口上縁より甲状軟骨上 緑まで正中切開を加えると，甲状軟骨の下甲状 結節を中心に輪状甲状靬帯の樎凹分認められる (写真 2). 舌骨, 甲状軟骨, 輪状軟骨には骨折 変形などけ所見を認めない。輸状軟骨から上:方 に甲状軟骨上甲状切痕まで正中切開を加え，喉 頭腔を開放すると右声帯は形状を失い，声帯前 部と推定される部位には因芽形成がみられ，そ の肉来は声門下腔を満している(写真 3 )。左声 帯は腫張が高度であるが，その形状は残ってお り，声門下腔は肉牙を満しているが傷害はな い.これらの肉牙を除去した。術後の声帯療着 を防止するため，あらかじめ作成してわいた純 金の $\mathrm{T}$ 字板 (写真 4 ) を, 両声帯前部の間に装着
した(写真 5 )。術創は Goldplatte 装着後, 1 次的に檤合した。術後の感染と政痕化防止には 抗生物質，副婜皮販ホルモン（プレドニン，デ カドロン）を投与した。

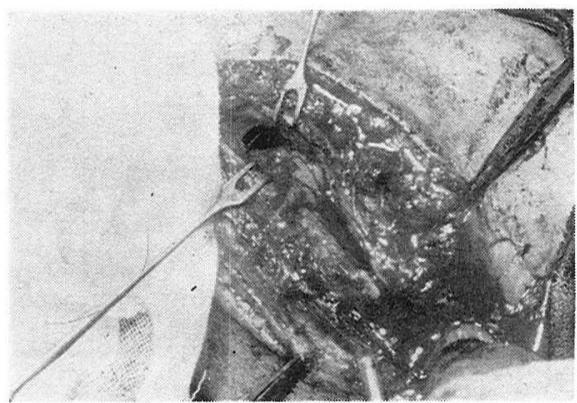

写真 3 喉頭腔を開放

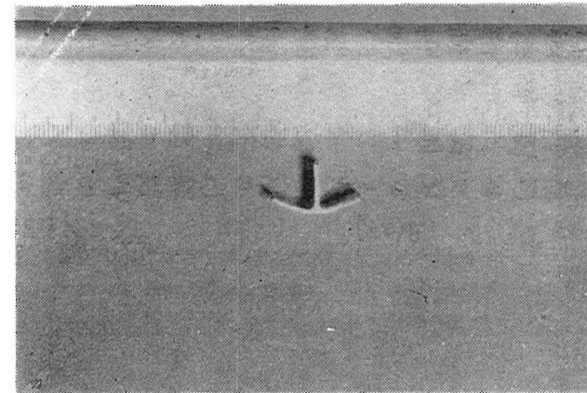

写真 4 厚さ $1 \mathrm{~mm}$, 各辺は $1 \mathrm{~cm}$

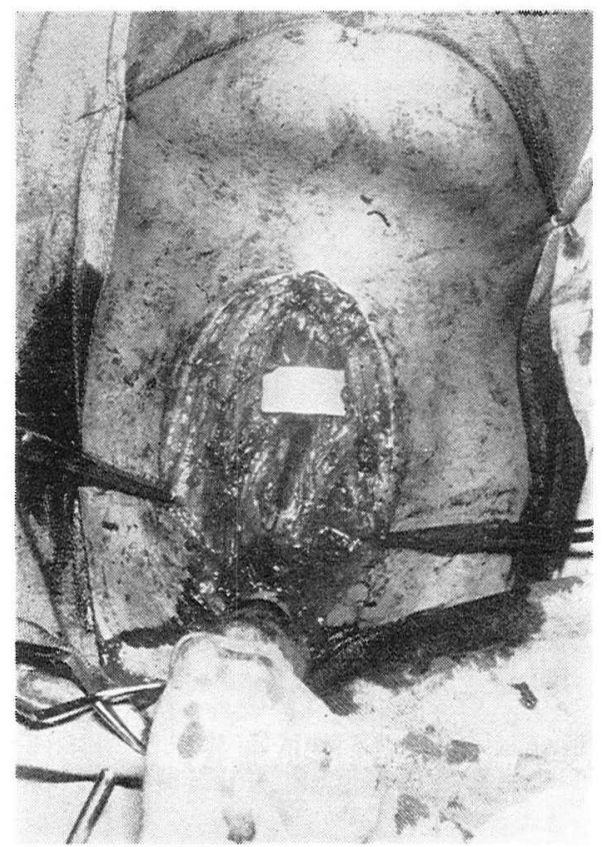

写真 5 Platte 装 着 


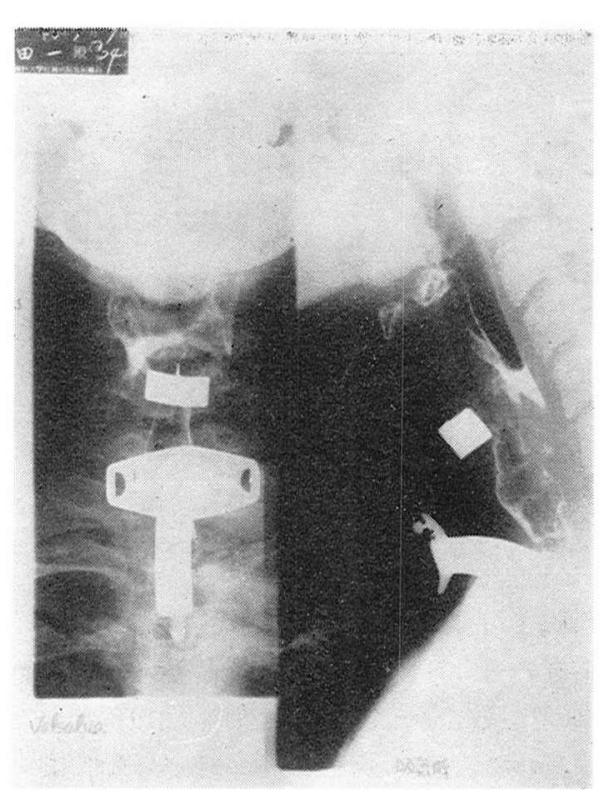

写真 6 Platte の位置を示す

翌日，カニューレ管口を指で閉鎖さすと発声 が可能となった，術後 3 日目より厳重な看視の もとに，カニューレ管口を綿栓し，套管拔去の 準備を開始した．Goldplatte 装着の期間は前 靧部皮虞の発赤, 腫張, 圧痛に注意し, 喉頭鏡 検查で声帯前部の声門裂にみられる金板を観察 し，Platte の位置は頸部レ線写真で確認した (写真 6 ).

7 月14日，T字板挿入後44日目に全身麻醉下 亿前頸部に再切開を施し，Platte を除去しカ ニューレを抜去して, 気切口は紏創忬で閉鎖し た. 同時に喉頭直達鏡検查で声門，声門下腔に 肉芽が発生していないととを碓認した。套管抜 去後27日目に気切孔は自然閉鎖し，9月 2 日退 院した．治療経過の概略は表 1 亿示す通りであ る.
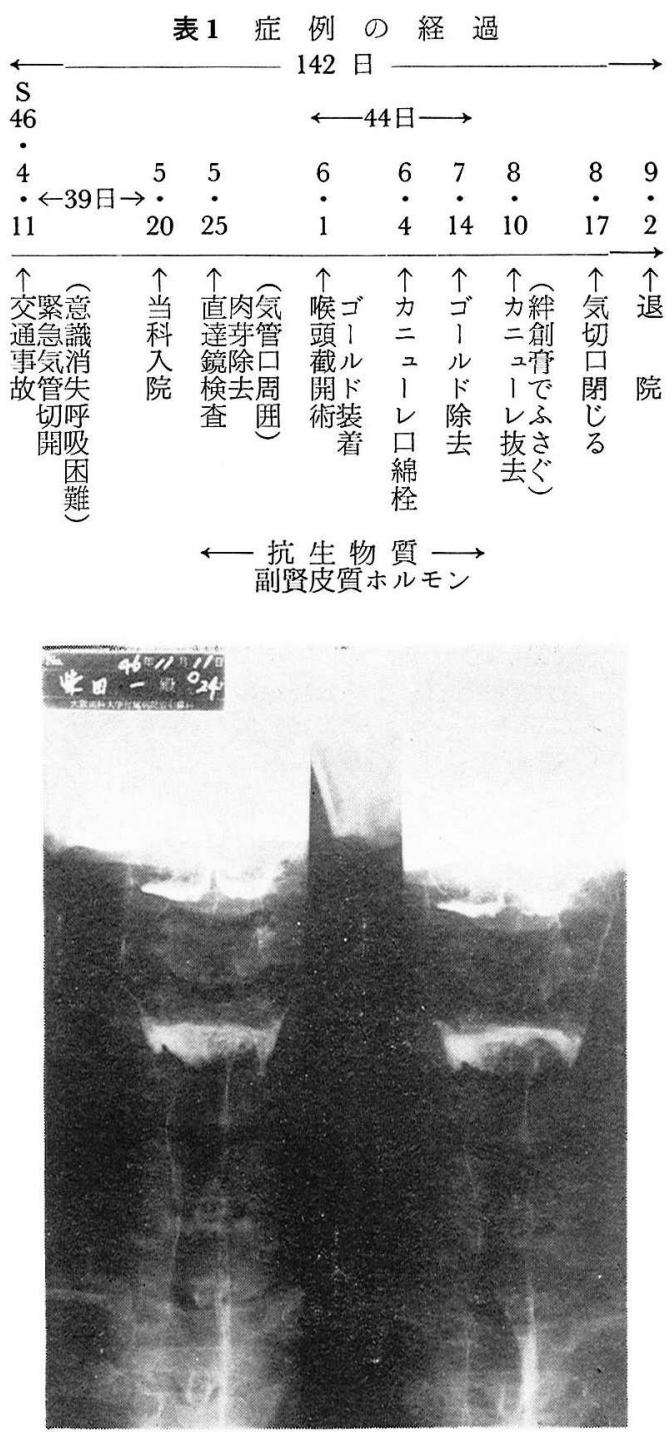

写真 7 退院後の Laryngogram

退院後は週 1 回の定期検診を行なった。声带 前部に軽度の癒着を認ぬ, 声帯の前後径が短く なった状態で治痖している. Laryngogram で は声門下腔は十分に拡大している(写真 7).

\section{III 総括ならびに考按}

喉頭外傷の問題点は, 受伤直後の生命保持と 2 次的に発生する喉頭狭窄および発声障害であ る. 過去の報告例を分析すると, 喉頭外稘の中 でわれわれが遭遇するのは，前者の場合は稀れ
でほとんどが後者の場合である．受笏後の症例 が耳厸咽喉科で治療される経過は表 2 の如くで ある。啒頭狄窄症の治療に先立ち, 狭窄の部位, 笨囲，程度を知るため種々の検査を行ない治療 


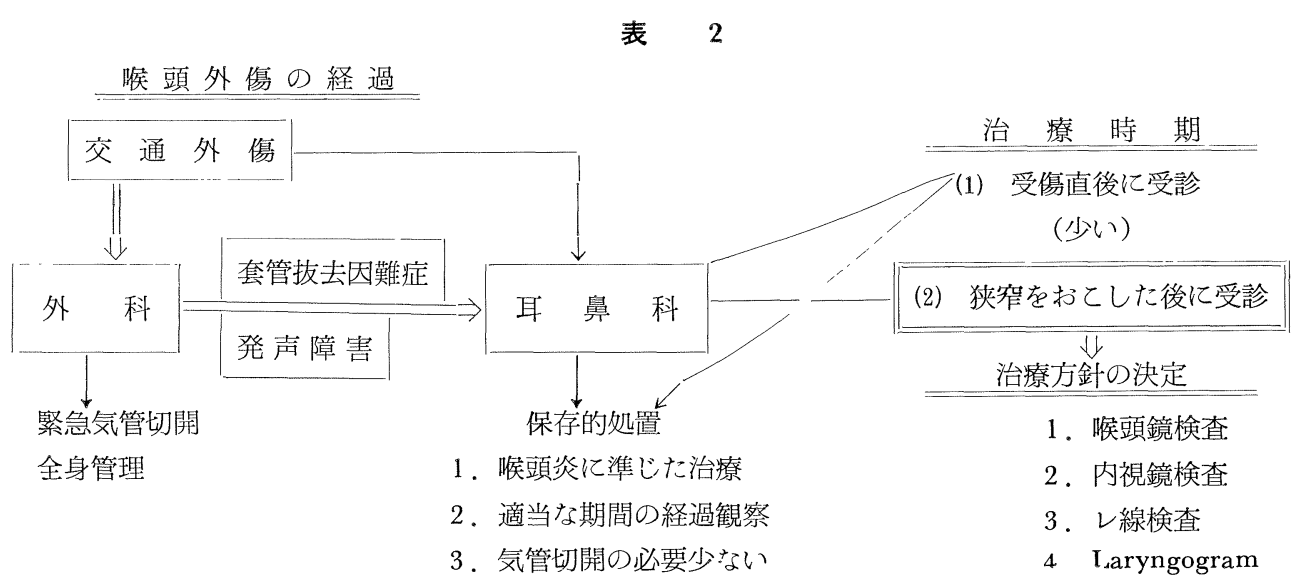

表 3 傷害部位による分類(広戸)

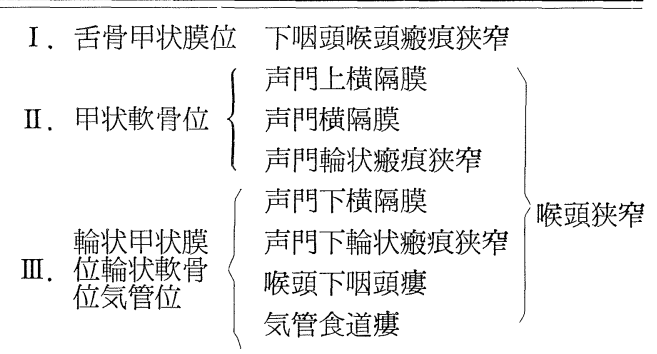

方針を決定するととが重要である（表 1)。広戸 ${ }^{2)}$ は傷害部位により表 3 の如く分類している. われわれの症例は広戸の分類に従うと III， III 属する症例である。

喉頭狭窄の治療は case by case に多種多様 の方法が諸家により報告されているが(34)576)7)， 治療の原則は殿頭腔，気管腔をいかにして拡大 するかである，切替ら ${ }^{8)}$ は狭乍の実態に応じた 治療の必要性を強調し, 狭窄の実態を喉頭・気 管枠の欠損, 内壁の瘢痕性肥厚，両者の合併の 3 つの状態に分類し，喉頭・気管を形成する組 織の特性を計算に入れた数回の計画的な操作が 配慮されるべきであり，更に患者と医師の協力 と忍耐が治療の成否を決すると述べている。わ れわれの症例は治療前の検査によって, 声門の 拡大と声門下腔の清掃の必要性が考光られ，術 後の声带の癒着をいか沉して防止するかであ った。本田ら ${ }^{9)}$, Frenzel ${ }^{10)}$ が強調する如く, 声 帯瘾着に対する処置では前連合の療着防止が最
も問題となる。術後の前連合癒着を避けるため $\mathrm{T}$ 字板のPlatte を両側声带間にに装着し，損 傷部の上皮化をまって 2 次的に摘出する方法が 用いられる.内田 ${ }^{11)}$ はセルロイド板を, $\mathrm{Mc}$ Naught ${ }^{12)}$ はタンタルム T字板を使用してい る. 広戸 ${ }^{2)}$ は $\mathrm{T}$ 字型板の择入の代りに中間層皮 弁の植皮を行ない，声門の形に適合したビニー ル管で圧抵する方法とシリコンゴムの T字板挿 入法とを比較して， $\mathrm{T}$ 字板挿入法の方が操作が 簡単で, 効果も確実であると述べている.われ われが $\mathrm{T}$ 字板の材料として純金を用いたのであ るが，その理由は Gold は生体に対する障害が 少く, 金板が柔いため工作が容易である点に着 目したてとである. また，歯科大学に勤務して いる関係上，Gold が容易に入手できることも 理由の 1 つである. 挿入した $\mathrm{T}$ 字板を広戸は 3 週間後に, McNaught は2 力月後に摘出して いるが，本症例は40日を過ぎる頃より前頸部に 圧痛を来したため, Platte 装着後44日目に除去 した．同時に套管も抜去することができたが， 前連合部のある程度の瘺着は避けられず喉頭の 前後径が短くなった状態で治癒した。

本症例を比較的短期間に治痛し得たのは, 第 1 亿 1 側の声帯麻瘏がなかったとと, 第 2 亿喉 頭 ・気管枠の傷害が軽度で欠損がなかったて と, 第 3 亿適切な気管切開が行なわれていたて と,すなわち, 気管切開が損傷部位より離れた 下方で行なわれていたととである. 


\section{IV 結—語}

124 才, 男子の外傷性喉頭狭窄症例を報告した。

2 治療の主体は純金を材料とした T字板挿入法である.

3 Goldplatte 挿入による局所反応はなかった。

稿を終るにあたり御指導ならびに御校閱戴きました浅井良三教授に深謝します，症例を紹介して戴いた播 磨病院耳鼻咽喉科医長矢内一郎博士に謝意を表します。

本論文の要旨は第33回耳鼻臨沐総会において発表した。

\section{文献}

1) Ernst Seifert : Handbuch der Speziellen Chiru rgie des Ohres und oberen Luftwege. IVBd, Curt Kabitzsh-Verlag S. 281, 1922

2）広戸幾一郎：喉頭外傷の治療, 耳展 8：10; 1965(昭40).

3）久保隆一, 調賢哉 : 瘀痕性喉頭狭窄の一治験 例，耳鼻と臨床 $8: 249 ， 1962$ (昭37)

4) 高橋 良, 飯田 太 : 喉頭狭窄に対する口腔粘膜 の移植, 耳展 $8: 440,1965$ (昭40)

5) Conley, J.J. : Reconstruction of The Subglottic Air Passage. Ann. Otol. 76 : 793, 1967

6) Ogura, J.H. and Power, W.E. : Funktional Restirution of Traumatic Stenosis of The Larynx and Pharynx. Laryngoscope $74: 1081,1964$

7）岩沢俊三，他：肋軟骨を用いた外傷性喉頭㹨窄症 の1治験例について, 耳展 $40: 683,1968$ (服 43)

〔抄 録〕
8）切替一郎，他：喉頭頸部気管狭窄の手術的療法, 気食 $20: 18 ， 1969$ (昭44)

9）本田芳男，他：外因性喉頭外傷について 耳展 $35: 332,1964$ (昭39)

10) Frenzel, H. : Wiederkerstellung der Vorderen Commiser bei Narbens tenosen des Kehlkopfes durch Verwendung einer Paladon-Flügelplate HNO-Wegweiser 1, 317, 1949

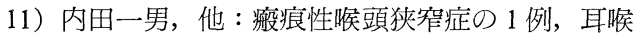
$35: 55,1363$ (昭38)

12) McNaught, R.C. : Surgical Correction of Ante rior Web of the Larynx. Laryngoscope 60 : 264, 1950

$\left.\begin{array}{l}\text { 原槁到着 炤和 } 47 \text { 年 } 2 \text { 月 } 24 \text { 日急載 } \\ \text { 別刷請求先 毛利 学 } \\ \text { 焉 } 540 \text { 大阪市東区京橋 } 1 \text { 丁目 } 4 \\ \text { 大阪歯科大学附属病院耳鼻咽喉科 }\end{array}\right)$

\section{鼓 膜 移 植一材料と技術の分析一 Tympanic Membrane Grafting - Analysis of Materials and Techniques - \\ Ronald, W. Strahan, et al. (Los Angeles, Calif.) \\ Ann. Otol. $80: 854 \sim 860,1971$}

鼓室成形 I 型飞対し，前肘静脈弁，側頭筋筋膜およ び耳介軟骨膜を用い，それぞれの場合の鼓膜穿孔閉鎖 率および聴力改善率を比較検討した。 483 例のうち medial graft 183例, lateral graft 301 例施行.

medial graft の場合の鼓膜穿孔閉鎖率および聴力 改善率は側頭筋筋膜使用時，それぞれ $87 \% ， 82 \% ，$ 軟
骨膜 $86 \% ， 90 \% ，$ 静脈弁 $50 \% ， 91 \%$ である.

Lateral graft の場合のそれは, 側頭筋筋膜使用侍, 86\%，67\%，軟骨膜87\%，94\%，静脈弁 $67 \% ， 91 \%$ で ある.

この様に静脈弁使用の場合には，他のものに較べて 鼓膜再穿孔の率が高い. 